\title{
Elaboration and costs multi-nutritional blocs with goatee leaves (Pithecellobium acatlense) consumed by goats in the Mixteca Poblana, Mexico
}

\author{
Jorge Hernández*, Lorenzo Carreón, Oscar A. Villarreal, Florencia Garcia, Julio C. Camacho \\ Faculty of Veterinary Medicine and Zootechny, Benemérita Universidad Autónoma de Puebla (BUAP), Puebla, Mexico; \\ *Corresponding Author: ovichiv_05@yahoo.com
}

Received 24 October 2013; revised 15 January 2014; accepted 12 February 2014

Copyright (C) 2014 Jorge Hernández et al. This is an open access article distributed under the Creative Commons Attribution License, which permits unrestricted use, distribution, and reproduction in any medium, provided the original work is properly cited. In accordance of the Creative Commons Attribution License all Copyrights ¿ 2014 are reserved for SCIRP and the owner of the intellectual property Jorge Hernández et al. All Copyright (c) 2014 are guarded by law and by SCIRP as a guardian.

\section{ABSTRACT}

The elaboration of multinutritional blocs (MB) is an alternative that allows supplement energy, protein, vitamins and minerals, and additionally, it can be administered and take natural resources as protein banks, mainly in the dry season, raising their cost and the concentrates decreasing profitability to producers. An aid is green or dried foliage of the tree-shrub of the Mixteca Poblana that drop their leaves to the ground (dry hay) in the dry season, thus becomes valuable forage consumed by goats, being great for your protein content and low cost in diets of small ruminants in silvopastoral production systems, at the dwindle the foliage of woody perennials in a time of the year. The aim of this study was to develop and meet production costs multinutrient blocks with goatee sheets (Pithecellobium acatlense) consumed by goats in the Mixteca Puebla. The study was done in the community of Tehuaxtla, belonging to the municipality Piaxtla in the Mixteca Poblana, which shows a secondary vegetation (arboreal, shrubby) that is consumed by goats in that region. 8 multinutritional blocks were used with Pithecellobium acatlense into two groups of $\mathbf{3 0}$ goats. Chemical analysis threw goatee $11.7 \%$ CP during the dry season and $14.8 \%$ CP for rains regarding consumption of $B M$ group $A$ showed $20 \%$ less compared to Group B, with respect to consumption of the block multinutrient the group A was 56 g/day/goat, whilst the group B has consumed 73 g/daylgoat, where he converted $\pm 0.14 \mathrm{~g} / \mathrm{goat} / \mathrm{day}$ for this preparation (MB), with a cost /goat when consuming block/8 days 0.14 USD.

\section{KEYWORDS}

Blocs; Supplementation; Trees; Goats; Silvopastoral

\section{INTRODUCTION}

The tropical regions of Mexico, held 36.8\% of the national inventory of sheep and in a smaller percentage goats inventory, however, the predominant production system is extensive or traditional, where the diet of the animals depends on grazing and browsing native species of trees and shrubs, whose nutritional value decreases rapidly with maturity; and during the dry season, food is very nutritious usable [1].

In this system, the caprines are kept in good state only 5 or 6 months of the year, retarding their growth and reproductive efficiency in the dry season; to counteract seasonal variations in forage availability is administered as a supplement block [2].

When supplementing molasses in multinutritional blocks represents an alternative for easy use by small farmers, in addition to several regional ingredients, it can be used in the manufacture of the blocks. No need to invest in infrastructure (feeder) is guaranteed even consumption of small amounts of the supplement for animals [3].

Multinutrient bloc is a dietary supplement rich in nitrogen, energy and generally also in minerals, occurring as a solid mass that cannot be consumed in large quantities by its hardness, due to a cementitious material that is added in its preparation. It makes the animal obtain nu- 
trients in small amounts to lick or bite the block [1]. So, the block is a sure way to incorporate the urea in the diet of cattle, facilitating the transportation, handling, storage and supply of animals.

Multinutrient bloc should be designed primarily to provide the nutrients necessary to satisfy the requirements of the microorganisms in the rumen, creating conditions within the rumen fermentation-promoting fiber digestion and bacterial protein production, which results in increased consumption of the basal diet (grasses or fibrous waste), improved digestibility and increased weight gain and milk production [3].

A feeding strategy which could improve productive efficiency in sheep and goatmeat to compensate for variations in the production of dry matter, protein, energy and digestibility in the rainy season, and support the shortage of forage during the dry season, is the use of foliage of trees and shrubs when mixed with other ingredients or raw materials in the region, as corn, hay, straw, NNP raising their nutritional value [4].

[4] notes that the use of blocks for kids' nutritional supplement improves the efficiency of utilization of shrubs in grasslands and in addition, they can be handmade in the production units [5,6]. In this sense it is necessary to test power with the use of those resources that can decrease the cost of the ration [7-9]. Such is the case of woody plants in Mexico (Leucaena leucocephala), which is an important source of forage for their wide availability because it provides fodder and/or fruit at different times of year in some parts of the country for cattle [10]. Moreover, a variety of native trees (legumes) with crude protein content between $14 \%$ and $18 \%$ are present in the tropics of Mexico [11].

Nutritional support in ruminants, is green or dry foliage of trees and shrubs in the Mixteca Poblana dropping their leaves on the ground (dry hay) in the dry season, becomes valuable forage to be consumed by the goats being the case, goateed (Pithecellobium acatlense) that provides low cost proteins in the diet of small ruminants production in silvopastoral systems [12]. The foliage of woody perennials at a certain time of the year, is the only option to produce subsistence food, the MB is an alternative that allows supplements: energy, protein, vitamins and minerals that is used during the dry season, it is a simple but great decision to feed the goats at low cost in the Mixteca. The objective of this study was to develop and determine costs of multinutritional blocks with leaves goatee (Pithecellobium acatlense) consumed by goats in the Mixteca Poblana, Mexico.

\section{MATERIALS AND METHODS}

\subsection{Location of the Study}

Work done on the Tehuaxtla community, in the municipality of Piaxtla south of Puebla Ranking the Mixteca region with parallel $17^{\circ} 59^{\prime} 00^{\prime \prime}$ and $18^{\circ} 12^{\prime} 30^{\prime \prime}$ north latitude, and meridians $98^{\circ} 10^{\prime} 54^{\prime \prime}$ and $98^{\circ} 21^{\prime} 36^{\prime \prime}$. Region with varied terrain and altitudes ranging from 700 to $2000 \mathrm{~m}$, its flora is composed of deciduous forest, thorny deciduous forest, xeric vegetation, scrub with izotes, secondary vegetation such as tree-shrub, and small localized oak forest areas and grasslands [13]. Warm humid climate with rains in summer and semidry with rainfall $(350-800 \mathrm{~mm})$ with an average temperature of $23^{\circ} \mathrm{C}$. It belongs to two morphological regions: the Petlalcingo riverbank south and Acatlán Valley, highlighting the hills as Large, Overweight, Pointer, Tule, Tecomatzin, Quiaxtepec. Its hydrography is given by Atoyac River Basin, which in the south is crossed from east to west by the rivers Acatlán and Mixteco, from Acatlán Valley and the Mixtecabaja, all those belonging to the upper region of the basin Balsas River [12]. Its fauna is given mainly by deer, coyote, skunk, armadillo, iguana, chameleon and rattlesnake key species [13]. Soil features as: Fluvizol (F), Vertizol (V), Rendzinas (R), Litozol (L) and Luvizol $(\mathrm{Lu})$, as described [14].

\subsection{Methodology}

He used 7 kilograms of milled leaves fifteen goatee trees (Pithecellobium acatlense) plant belonging to the legume family. Subsequently designated the following percentages of the ingredients: $35 \%$ foliage goatee, $40 \%$ molasses, $5 \%$ mineral salts, urea $5 \%, 10 \%$ of binder (cement) and 5\% corn stover, then by weighing all components on a hanging scale (watch type) for homogeneously mixed in a wheelbarrow and immediately emptied the component (mixture) in plastic buckets or laminated with 6 liters capacity, which used a machine (bloc construction) to compact the blocmultinutrient developed.

The blocs were left seven days for drying and hardness, to finally be placed in two groups of 30 goats (A and B) to check their consumption in the corral. Drying and milling was performed in the laboratory of nutrition in the BUAP FMVZ through the traditional method in oven with forced circulation of air for 72 hours at $35^{\circ} \mathrm{C}$ for dehydration of leaves in the case of grinding, the dried material was ground in a hammermill mm mesh to 3000 $\mathrm{rev} / \mathrm{min}$.

The compositional analysis goatee (Pithecellobium acatlense) to obtain crude protein (CP) was by the Kjeldahl method in the laboratory of Food Science, Graduate School of slides, State of Mexico. The study duration was 8 months (February to September) in 2009. Descriptive statistics were applied through the SSPS 10 for Windows package.

\section{RESULTS AND DISCUSSION}

Pithecellobium acatlense or goatee, is considered a 
tree belonging to the legume family, it is also highly edible plant goats of the MixtecaPoblana. It was found that this is woody forage with high protein nutritional value, throwing in compositional analysis $11.7 \%$ protein in dry season, rainy season and protein percentage reached $14.8 \%$, PC values above some grasses consumed by ruminants, which reach an average of $4 \%$ to $12 \%$ [15].

Table 1, shows the composition of the blocks multinutritional processed and consumed by the two groups of goats belonging to the community in the township TehuaxtlaPiaxtla.

As shown in Table 1, the mixture was estimated multinutrient block per $10 \mathrm{~kg}$, performing another replica with the same formula, percentages and similar amounts, yielding $20 \mathrm{~kg}$ of multinutrient component. This yielded eight blocs of $2.5 \mathrm{~kg}$, which were placed 4/group placed goat considered in the study. With regard to Pithecellobium acatlense consumption by goats Mixteca region in the two groups managed in the study $(\mathrm{A}, \mathrm{B})$ multinutritional blocks, the group B showed 20\% higher in group A, in terms of popularity and taste when consumed consistently in 8 days allocated for consumption, this was quantified on the weight of the debris left by withdrawing the goats of the place assigned to the block for consumption during grazing. Is then determined in Table 2, the two weighings is estimated multinutritional remaining blocks in the two groups consumed goats considered in the study.

As shown in the above table, the group (goats) kept a better intake $\mathrm{B}$, as it remained for the duration of your supplementation multinutrient bloc averaged $1100 \mathrm{~kg} /$ period/weighing, it is probably due, and is an important point, consumption may have been affected in group $\mathrm{A}$ by age differences in the study groups and pen space, since the goat group $\mathrm{A}$, their mean age was 20 months and its space/animal was overcome by the group B, as shown in the Figure 1.

Some authors such as [16] indicate that there are several factors that affect consumption blocks, such as the hardness of this, forage availability, time of exposure of animals to blocs, level of urea in the block, physiological state and age of the animals however, do not discuss the pen space, since most of the studies indicate that they coincide in the use of block grazing. So, it was just like the age factor they studied animals with those found in this work, which could have affected the consumption of group A.

With respect to consumption multinutrient average bloc group A/goats was $56 \mathrm{~g} / \mathrm{day}$, as the group B the average consumed/goats was $73 \mathrm{~g} /$ day, it is important to note that consumption also depended multinutrcional block the type of ingredients that formed, time consumption and nutritional potential productive phase. As stipulated [17], in developing $\mathrm{BM}$ and supplement them in
Table 1. Parts and percentages multinutriciales blocks consumed by goats in the Mixteca Puebla in Mexico.

\begin{tabular}{|ccc|}
\hline Ingredients & $\%$ & $\begin{array}{c}\text { Amounts/block } \\
\text { considered component/in 10 kg }\end{array}$ \\
\hline Molasses & 40 & 4.0 \\
\hline Goat Beard's leaves & 35 & 3.5 \\
\hline Cement & 10 & 1.0 \\
\hline Urea & 5 & 0.5 \\
\hline Corn stubble & 5 & 0.5 \\
\hline Salts minerals & 5 & 0.5 \\
\hline Overall & $100 \%$ & $10 \mathrm{~kg}$. \\
\hline
\end{tabular}

cattle and sheep with higher percentages of protein, where consumption reached $600 \mathrm{~g} /$ day in large ruminants and in the case of sheep consumption reached 150 g/day, not to mention the extent of consumption for goats, however, reinforces this principle of the composition of the bloc to integrate nutritional potential of ingredients contained in it, as was the case, the BM experience in sheep with a composition: $40 \%$ molasses, urea $10 \%$, rice bran $40 \%, 5 \%$ cement with the same percentage salt administered to sheep grazing, as a result consumption ranged between 90 - 110 g/day and a $43.6 \%$ crude protein [18].

Looking at these results, the protein content was higher than that found with goatee (Pithecellobium acatlense) of $14.8 \%$ in the rainy season, which is at the top with $28.8 \%$ of those found in this tree, making a difference in quantity and cost of protein used in the diet of these small ruminants. This gives a premise in this study: the animal species in their production system in which they operate, depend on the quantity, quality and preference ingredient in blocmultinutrien, that the number and the high costs the ingredients to be used.

Initial weight was recorded in goats in groups (A and B) studied, finding a significant gain during the supplementation period with blocks, reaching an increase for group A of $115 \mathrm{~g} /$ day/goat, in the case of group B slightly reached a weight of $122 \mathrm{~g} /$ day/goat, which was not significant. In terms of costs and profitability of the blocks goateed multinutritional in goats studied the Mixteca region, maintain significant costs in developing cheaply multinutritional blocks, allocated to power systems, particularly in supplement diets in certain time or period, when there are low amounts of forage or feed by maintaining and growing profitable production in goats in the MixtecaPoblana, see Table 3.

From this table, as noted, the consumption cost is quite cheap block, as it costs $\$ 1.80 /$ goat compared to other supplement through grain or other feed, increase production costs in different production phases up to $25 \%$ or $45 \%$ when used in some production systems in ruminants 
Table 2. Weights and percentages in the block multinutritional consumed by goats in the Mixteca region.

\begin{tabular}{|c|c|c|c|c|c|}
\hline Goatsgroupsstudied & $\begin{array}{l}\text { Initial weight of the } \\
\text { blocmultinutrient }\end{array}$ & $\begin{array}{c}\text { Weighing multinutrient } \\
\text { bloc remains at } \\
4 \text { days }\end{array}$ & $\begin{array}{c}\text { Weighing multinutrient } \\
\text { bloc remains at } \\
8 \text { days }\end{array}$ & Bloc kilograms consumed & Intake \\
\hline A & $2.5 \mathrm{~kg}$ & $1.7 \mathrm{~kg}$ & 0.8 & 1.7 & $68 \%$ \\
\hline B & $2.5 \mathrm{~kg}$ & $1.4 \mathrm{~kg}$ & 0.3 & 2.2 & $88 \%$ \\
\hline
\end{tabular}

Table 3. Ingredients and costs multinutritional blocs consumed by goats in the MixtecaPoblana.

\begin{tabular}{ccccc}
\hline Bloc ingredients & Ingredient amounts & Cost/lot/bloc & Full cost/8 blocs & Cost of consumption/goat \\
\hline Molasses & $8 \mathrm{~kg}$ & $\$ 2.80 / \mathrm{kg}$ & $\$ 22.40$ & $\$ 0.37$ \\
$\begin{array}{c}\text { Goatee foliage } \\
\text { (Pithecellobium acatlense) }\end{array}$ & $7 \mathrm{~kg}$ & $\$ 6.25 / \mathrm{kg}$ & $\$ 50.00 /$ cosecha & $\$ 0.83$ \\
Maize stover & $1 \mathrm{~kg}$ & $\$ 0.56$ & $\$ 4.50$ & $\$ 0.08$ \\
Urea & $1 \mathrm{~kg}$ & $\$ 1.65$ & $\$ 13.00$ & $\$ 0.22$ \\
Mineral salts & $1 \mathrm{~kg}$ & $\$ 1.50$ & $\$ 12.00$ & $\$ 0.20$ \\
Cement & $2 \mathrm{~kg}$ & $\$ 0.75$ & $\$ 6.00$ & $\$ 0.10$ \\
Totals & $20 \mathrm{~kg}$ & $\$ 13.51$ & $\$ 108.00$ & $\$ 1.80$ \\
\hline
\end{tabular}

$\$=$ Mexican pesos. "Payment made to a relative of the producer for Pithecellobium acatlense harvest.

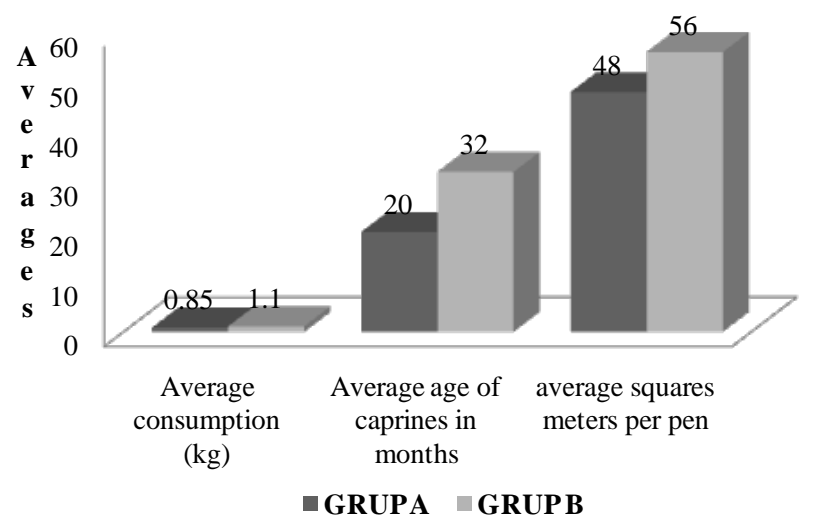

Figure 1. Averages with regard to consumption, age groups and corral goats in the MixtecaPoblana in Mexico.

as determined [16]. This show, that by providing multinutritional blocks with this type of tree fodder present in the MixtecaPoblana, gives significant results in production, ruminal welfare to promote more efficient and better forage, are completely positive economic and rate of return [19].

Table 4 shows the standard deviations in weight obtained during the initial and final weight in the groups studied with the use of the blocks multinutritional with goatee.

It is important to note that the above table the results in terms of average final weight of the two groups was $36.25 \mathrm{~kg}$; keeping with a ( $\pm \mathrm{SD}$ ) of $4.73 \mathrm{~kg}$, which represent 0.49 gr cattle/goats to consume the blocmultinutrient during the eight days that were exposed for consumption, becoming $\pm 0.14 \mathrm{~g} /$ goat/day of this mixing.
Table 4. Standard deviations in groups A and B goats fed multinutritional blocs Tehuaxtla community in the MixtecaPoblana.

\begin{tabular}{cccccc}
\hline Variables & $\mathbf{N}$ & Minimum & Maximum & Mean & \pm SD \\
\hline Initial weight (kg) & 2 & $\mathrm{~A}=32$ & $\mathrm{~B}=38$ & 35 & 4.24 \\
Final weight & 2 & $\mathrm{~A}=32.9$ & $\mathrm{~B}=39.6$ & 36.25 & 4.73 \\
Age (months) & 2 & 20 & 32 & 26 & 8.48 \\
\hline Bloc consumption (kg) & 2 & 1.70 & 2.20 & 1.95 & 0.35 \\
\hline
\end{tabular}

\section{CONCLUSION}

Multinutritional blocs at different times of the year are a tool in animal nutrition of goats in the Mixteca Puebla. In conclusion, the percentage of Pithecellobium acatlense (goatee) was $14.8 \%$ crude protein, since it is a legume with high protein content. Moreover, it was well accepted by the goats of the Mixteca to consume, having a cost $0.14 \mathrm{USD} /$ goat during the time offered for consumption. Finally, the MB is an alternative to supplement in times of dry season and sustain goat production of Mixtec at low cost.

\section{REFERENCES}

[1] Amaro, G.R. (2013) Craftsmanship and use of molasses multinutritional blocks as a feed supplement for sheep. http://www.asmexcriadoresdeovinos.org/sistema/pdf/alim entacion/elaboracionartesanal.pdf

[2] Gutierrez, V.F. and Ayala, B.A. (2009) Use and development of blocks of molasses-urea multinutritional. http://www.iiaf.umich.mx/filenot/bloques.pdf 
[3] Fariñas, T., Mendieta, B., Reyes, N., Mena, M., Cardona, J. and Danilo, P. (2009) Using multinutritional blocks in ruminants. Technical Series: Technical Manual No. 92. Tropical Agricultural Research and Higher Education, Managua, 2009, 2-5.

[4] Gasmi-Boubaker, A., Kayouly, C. and Buldgen, A. (2006) Feed blocks as a supplement for goat kids grazing natural Tunisian rangeland during the dry season. Animal Feed Science and Technology, 126, 31-41. http://dx.doi.org/10.1016/j.anifeedsci.2005.05.024

[5] Ben-Salem, H. and Nefzaoui, A. (2003) Feed blocks as alternative supplements for sheep and goats. Small $R u$ minant Research, 49, 275-288.

http://dx.doi.org/10.1016/S0921-4488(03)00144-5

[6] Birbe, B. (1998) Physical Assessment of molasses-urea blocks multinutritional, with different levels of rock phosphate and Gliciridiasepium leaf meal, acceptability and productive responses of cattle. Proceedings of the Third International Workshop Silvopastoral: Trees and Shrubs in Livestock Experimental Station Huatey Indio, Matanzas, 25-27 November 1998, 161-165.

[7] Ramírez, L.R.G. (2009) Ruminant nutrition extensive systems. 2nd Edition, Editorial Threshings, Mexico.

[8] Andrade, M.H.M. (2006) Nutrition and feeding of sheep in intensive systems. In: Seminar V Memories Sheep Production in the Tropics, Tabasco 2000 Planetarium, Walk Extension Tabasco s/n, Villahermosa Tabasco, Mexico, November, 1-15.

[9] Tobía, C. (1996) Artisanal and semi-industrial Development nutritional blocks for ruminants. The garrapatoso. In: Decanate of VeterinaryScience. Universidad CentroOccidental Lisandro Alvarado, Barquisimeto, 13, 14-17.

[10] García, E.D. and Medina, G.M. (2006) Chemical composition, secondary metabolites, nutritive value and relative acceptability ten fodder trees. Tropical Animal Science Magazine, 24, 233-250.

[11] Meléndez, N.F., Báez, R.V.A., López, J., Tejada H.I., Shimada, M.A. and Goñi C.S. (2000) Feeding of ruminants in the tropics. General and special topics. University of the State of Mexico, Mexico.

[12] Hernández, H.J.E. (2006) Valuations and goat raising in the MixtecaPoblana: Socioeconomics and tree-shrub resources. Doctoral Thesis, University of Camagüey, Camagüey.

[13] INEGI (2000) Geographical synthesis of Puebla. Electronicbook, Mexico.

[14] Guizar, E. and Sánchez, A. (1991) Guide for the recognition of the major high Balsas trees. Chapingo Autonomous University, Montecillo.

[15] García, E.D., Medina, G.M., Clavero, T., Humbria, J., Baldizan, A. and Domínguez, C. (2008) Preference for goat fodder trees in the lower area of the Venezuelan Andes. Scientific Journal, 5, 549-555.

[16] Fernández, G., San Martin, F. and Escurra, E. (1997) Using blocks nutritional supplementation to grazing sheep. LivestockResearch Magazine, 8, 29-38.

[17] Gutiérrez, V.E. and Ayala, B.A. (2009) Use and development of blocks of molasses-urea multinutritional. http://www.iiaf.umich.mx/filenot/bloques.pdf

[18] Soto, C.R. and Martínez, R. D. (2001) Using blocks of molasses and urea in the intensive fattening calves Creoles. Latin American Archives of Animal Production, 9, 99-103.

[19] Araujo, F.O. (2002) Polygastric: Recent advances in ruminant nutrition. Proceedings of the XI Venezuelan Congress of Animal Production and Industry, Trujillo, 22-26 October 2002, 1-9. 